\title{
What's wrong with the coastal waters of Spelman Strait, Indonesia: Sustainable reef fisheries management is required
}

\author{
Rahmat Kurnia ${ }^{\mathrm{a}}$, Muis ${ }^{\mathrm{b}}$, Agus Alim Hakima \\ ${ }^{a}$ Department of Aquatic Resources Management, IPB University, Lingkar Akademik Street, IPB Dramaga Campus, Bogor 16680, \\ West Java, Indonesia [+62 251-8622932] \\ ${ }^{\mathrm{b}}$ Fisheries Agribusiness Department, Faculty of Fisheries and Marine Sciences, Halu Oleo University, Kendari, Indonesia
}

\section{Article Info:}

Received: 16 - 08 - 2021

Accepted: $01-10-2021$

Keywords:

EAFM, fishing for coral reefs, MDS, small-scale, sustainability

Corresponding Author:

Rahmat Kurnia

Department of Aquatic

Resources Management, IPB

University;

Tel.: +62-251-8622932

Email: rahmatku@apps.ipb.ac.id

\begin{abstract}
Reef fish in Spelman strait, Indonesia, is one of the fishery resources of considerable economic value. Unfortunately, there is still the use of unfriendly resources equipment (destructive fishing) that causes potential social problems. In this study, all components of the EAFM (Ecosystem Approach to Fisheries Management) are composed of 6 domains, namely (1) fish stocks, (2) environment and ecosystem, (3) fishing techniques, (4) culture, (5) social, and (6) institutional are analyzed combining with MDS (Multidimensional Scaling). This research aims to find out the root solution for managing coral reefs in the coastal waters of Spelman Strait. The results showed that the sustainability status review in the fishery resource domain, the environment and ecosystem domain, the fishery technique domain, the social domain, and the economic domain were 87.69, 88.17, 51.22, 51.61, and 72.67 , respectively, which were in the sustainable category. Meanwhile, the sustainability status review in the institutional domain was 42.15 , which was in the category of less sustainable. Institutions are the primary base for reef fishery protection in the Spelman Strait.
\end{abstract}

How to cite (CSE Style $8^{\text {th }}$ Edition):

Kurnia R, Muis, Hakim AA. 2021. What's wrong with the Spelman Strait coastal waters, Indonesia: Sustainable reef fisheries management is required. JPSL 11(3): 408-418. http://dx.doi.org/10.29244/jpsl.11.3.408-418.

\section{INTRODUCTION}

Reef fish is one of the fishery resources of considerable economic value, such as grouper, snapper, red snapper, napoleon, and others. About 16 percent of Indonesia's overall fish exports come from reef fisheries (Supriharyono, 2000). This fishery product is the focus of fishermen in supporting the household economy, besides that, it is also an area's food security. There is a very high demand for reef fish in local, domestic, and global markets. The coastal waters of Spelman Strait are one of the producers of coral fisheries in Central Buton Regency, Southeast Sulawesi Province.

The coastal waters of Spelman Strait are rich in reef fish stocks and are a cornerstone of small-scale fishermen inhabiting Mawasangka District's coastline (Muis et al., 2019, 2020). Muis et al. (2019) reported that the reef fish in the coastal waters of Spelman Strait consisted of 8 families and 14 genera. In Indonesian waters, about 3000 species belong to 17 orders and 100 families (Kuiter, 1992), while in Indonesia, there are 2057 reef fish species from 113 families (Allen and Adrim, 2003). 
The market for reef fish is also growing along with the raising of the earth's population. The growing demand for reef fish would cause both environmentally friendly and destructive fishers to exploit the coral reef ecosystem with various fishing equipment. Fishers in the coastal waters of the Spelman Strait have multiple types of fishing equipment such as spikes, bows, hand lines, and the use of explosives. The use of fishing equipment, which has always been a social issue, is unfriendly resource (destructive fishing). Muis et al. (2020) reported that the use of bomb fishing equipment in the coastal waters of Spelman Strait caused high dead corals (33.17\%), which decreased live coral cover $(37.71 \%)$.

Harm to coral reef habitats from destructive fishing practices will cause potential social problems. Due to discrepancies in fishing gear on the same estate, these social issues can cause social tensions (Purnama et al., 2015; Lorenzo et al., 2019). Thus, a model of sustainable management of coral reefs is required. This research aims to manage coral reefs in the coastal waters of Spelman Strait by combining ecological, social, economic, and institutional components to produce a solution. This study is also carried out for the first time by combining all components of the EAFM (Ecosystem Approach to Fisheries Management) composed of 6 domains, namely (1) fish stocks, (2) environment and ecosystem, (3) fishing techniques, (4) culture, (5) social, and (6) institutional (KKP et al., 2012; KKP, 2014) and added with other attributes, according to the current research area conditions.

Management of fisheries in Indonesia and other countries using MDS has been carried out with various methods, such as the marketing of fish in Sendangbiru, East Java (Abidin and Primyastanto, 2017); sustainability evaluation of fisheries cooperatives in Gulain Province, Iran (Allahyari, 2010); management of fisheries in the outermost small island of Miangas Island (Baroleh et al., 2016); capture fisheries in Tegal District (Nababan et al., 2007); fisheries management in Southern Brazil (Castello et al., 2009); small-scale fishing in Guyana (Cisse et al., 2014); fishing in Bengkulu waters (Erwina et al., 2015); flying fishing in Takalar District (Fitrianti et al., 2014), fisheries evaluation in Northern Brazil (Isaac et al., 2009); fisheries in Seribu Island (Kholil and Dewi, 2014); fishery production system in Penambuco, Brazil (Lessa et al., 2009); status quo system of fisheries in Espirito Santo, Brazil (Martins et al., 2009); and an indicator of capture fisheries performance in Indonesia (Hartono et al., 2005). The research aims to find out the root solution for managing coral reefs in the coastal waters of Spelman Strait.

\section{MATERIALS AND METHODS}

\section{Description of the Study Sites}

The study was conducted from December 2018 to June 2019 in the coastal waters of Spelman Strait, Central Buton Regency (Figure 1).

\section{Data Measurement}

Data were ecologically obtained through direct field observations during two fishing seasons (western and eastern seasons), while social, economic, and institutional data were obtained from respondents by using interviews through FGD (Focus Group Discussion) to reef fishermen, fishery community members, religious leaders, educators, youth leaders, local government (related agencies), community leaders, police agencies, TNI agencies, and heads of agencies.

\section{Data Analysis}

Assessment of the sustainability status of coral reefs management in the Spelman Strait's coastal waters was performed using the MDS (Multidimensional Scaling) method and an R program tool. In representing the sustainability status of the domain, each management dimension/domain has different indicators (attributes), and its representation is determined by the range of values produced in the ordination scale with the categories in Table 1. 
Table 1 Category of a sustainability index

\begin{tabular}{cc}
\hline Index Value & Sustainability Category \\
\hline $0-24.99$ & Bad; Unsustainable \\
$25-49.99$ & Less; Less Sustainable \\
$50-74.99$ & Enough; Sufficiently Sustainable \\
$75-100$ & Well; Very Sustainable \\
\hline
\end{tabular}

Source: Pitcher, 1999; Pitcher and Preikshot, 2001

The results of the sustainability index obtained were then checked using a triangular and uniform distribution based on a Monte Carlo simulation. The smaller the difference between the sustainability index and the simulation on Monte Carlo, the more accurate the results would be. The approach value for Monte Carlo shows the effect of the miss (miss) or the impact of a relatively small error in scoring. According to Pitcher (1999), Pitcher and Preikshot (1999), Pitcher and Preikshot (2001), Kavanagh and Pitcher (2004), Pitcher et al. (2013), the Monte Carlo value should be used as a reference measure for random error impacts. Fauzi and Anna (2002) emphasized that Monte Carlo analysis can indicate errors caused by scoring on each attribute, multidimensional scoring differences due to different viewpoints, repetitive data analysis method, and errors in the input of data or incomplete data.

Analysis ability to evaluate critical attributes for each domain. Leverage analysis is used to see how other factors impact each domain's sustainability score if one attribute is excluded from the study. The sustainability score's sensitivity level can be seen by providing one of these attributes (Table 1).

The sustainability of the management of coral reefs in the coastal waters of the Spelman Strait is defined by 47 indicators (Adrianto et al., 2016), consisting of 11 (eleven) indicators in the domain of fish stocks, 6 (six) indicators in the domain of habitats and ecosystems, 5 (five) indicators in the domain of fishing techniques, 7 (seven) indicators in the social domain, and 9 (nine) economically relevant measures (Table 2).

Table 2 Domains and measures for the sustainable management of coral fisheries in coastal waters of Spelman Strait

No. Domain of Sustainability Indicator of Sustainability

1. CPUE (Catch Per Unit Effort)

2. Trends in fish size

3. Composition of catch species

4. Range collapse

1. Fish Resources

5. Species Endangered, Threatened, and Protected (ETP)

6. Diversity

7. Domination

8. Uniformity

9. Biomass

10. Abundance

1. Water quality

2. Seagrass

2. Habitat and Ecosystem

3. Mangrove

4. Coral reefs

5. Unique habitat

6. Climate change

1. Destructive fishing

3. Fishing Technique 2. Modification of fishing gear

3. Capturing capacity and effort 


\begin{tabular}{|c|c|c|}
\hline No. & Domain of Sustainability & Indicator of Sustainability \\
\hline & & $\begin{array}{l}\text { 4. Selectivity of fishing gear } \\
\text { 5. The conformity of the function and size of the ship with legal } \\
\text { documents }\end{array}$ \\
\hline 4. & Social & $\begin{array}{l}\text { 1. Participation } \\
\text { 2. Conflict } \\
\text { 3. Local wisdom } \\
\text { 4. Fishing patterns } \\
\text { 5. Sand mining } \\
\text { 6. The garbage problem } \\
\text { 7. Level of knowledge }\end{array}$ \\
\hline 5. & Institution & $\begin{array}{l}\text { 1. Compliance with the rules of the game } \\
\text { 2. Completeness of the rules } \\
\text { 3. Mechanism } \\
\text { 4. Management plan } \\
\text { 5. Level of institutional synergy } \\
\text { 6. Capacity of stakeholders } \\
\text { 7. The involvement of religious leaders in management } \\
\text { 8. Local content } \\
\text { 9. Collaboration of figures }\end{array}$ \\
\hline 6. & Economic & $\begin{array}{l}\text { 1. Ownership of assets } \\
\text { 2. Income } \\
\text { 3. Savings ratio } \\
\text { 4. Alternative livelihoods } \\
\text { 5. Market } \\
\text { 6. Jobs } \\
\text { 7. Catch production } \\
\text { 8. Fish landing sites TPI / PPI } \\
\text { 9. Cold storage }\end{array}$ \\
\hline
\end{tabular}

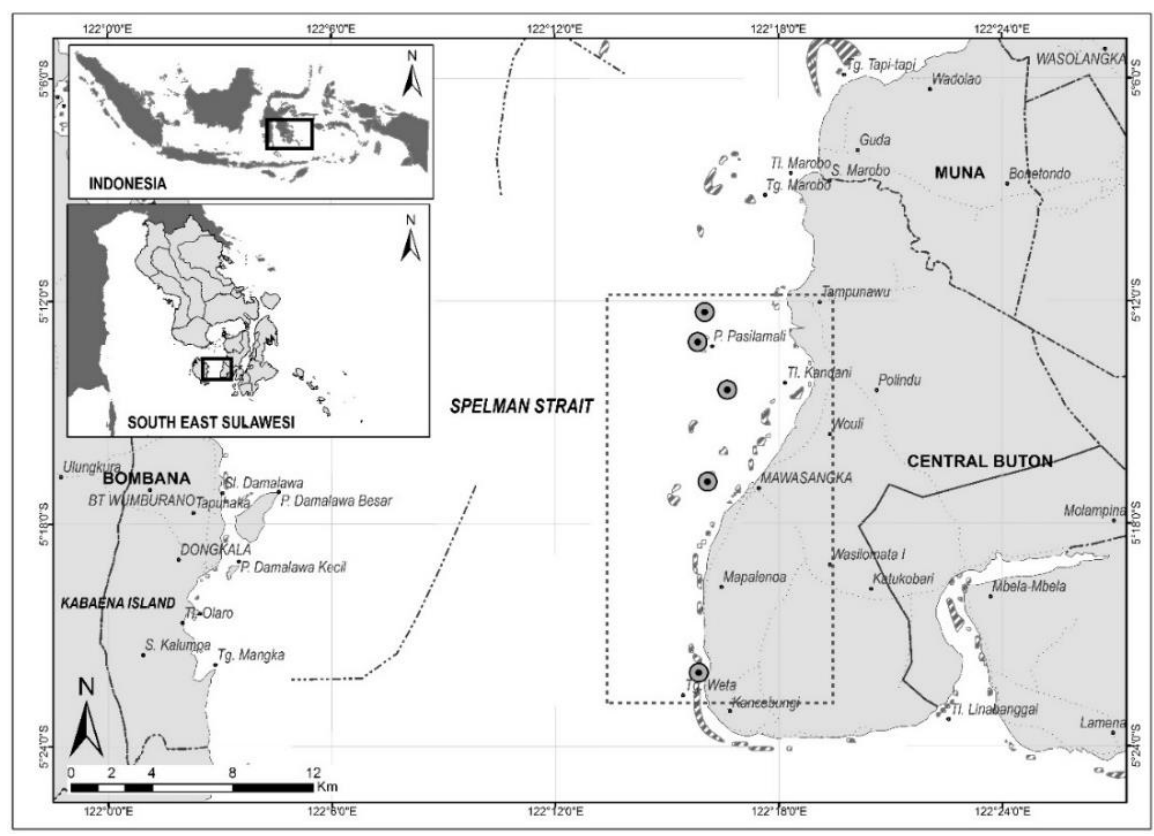

Figure 1 Map of the study site 


\section{RESULTS AND DISCUSSION}

After an overall review phase of several domains (Table 1), a sustainability index is obtained in the coastal waters of the Spelman Strait, as shown in Figure 2.

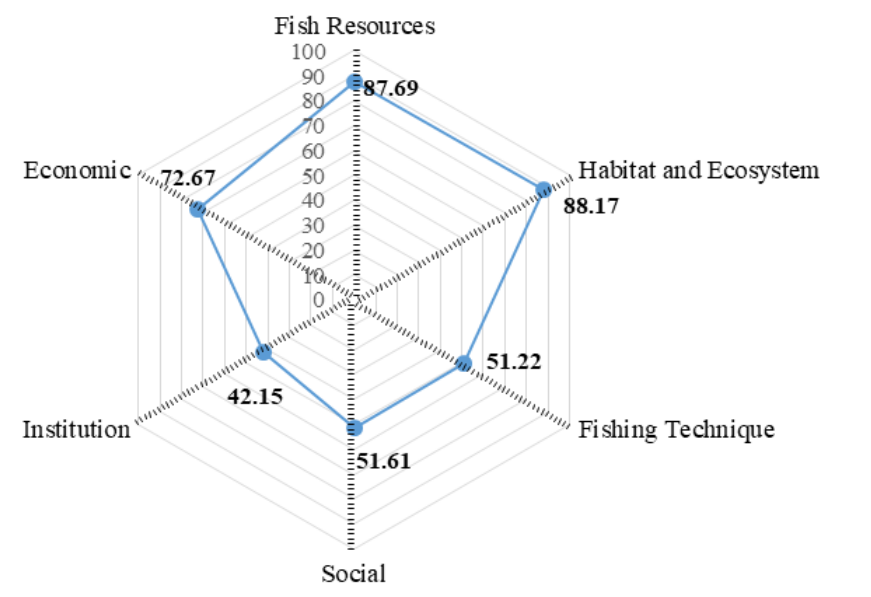

Figure 2 The survival ranking for coral fisheries

\section{Fish Resources Management}

The sustainability status review in the fishery resource domain (Figure 2) was in the sustainable range (75-100) at 87.69. The high sustainability index in the fishery resource domain indicates that the quality of fish stocks in the Spelman Strait waters is in good condition and enables them to be used sustainably with the same effort.

CPUE (Catch Per Unit Effort) is a capture effort per season or so-called productivity of fishermen. Fishermen's catch of fish is equivalent to the surplus in a stock of fishery capital (Boesono et al., 2011). CPUE of coral fishing in coastal waters of Spelman Strait is conducted within 1 (one) year, given that no previous data are available. Catch up info, 4 (four) times a week (Figure 3).

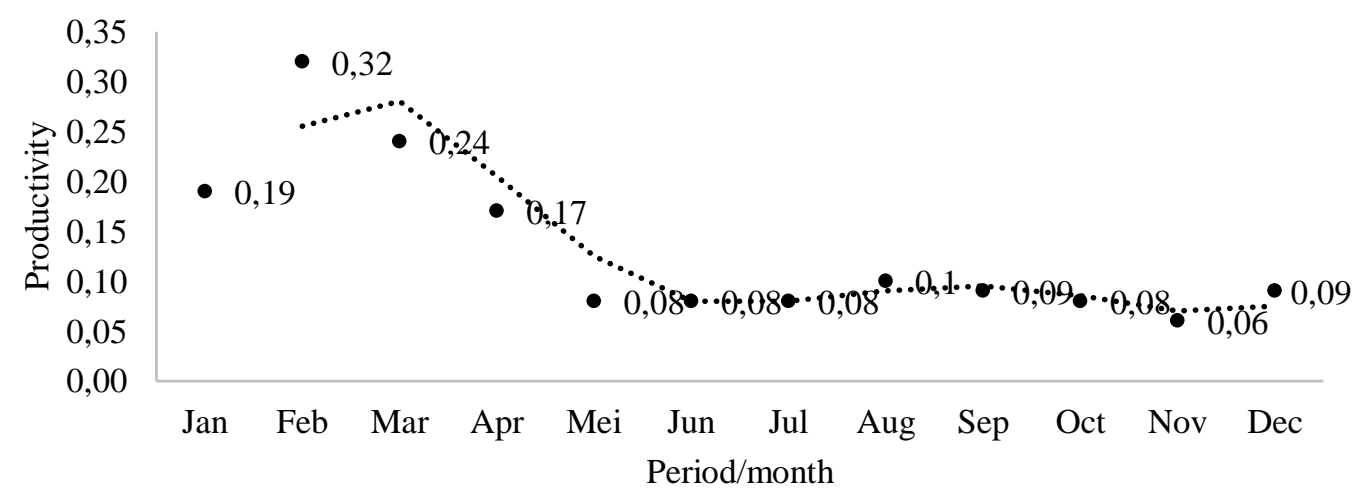

Figure 3 CPUE of 1-year reef fishing in Spelman Strait's coastal waters

The resulting domain of fish resources indicates that the regular CPUE indicator decreases with a value of $10.65 \%$ (Figure 3). The trend of the size of the captured reef fish is decreasing. As recorded by Yulianto et al. (2016) in Karimunjawa National Park, the grouper fish CPUE dramatically reduced to just 0.06-0.15 kg per fishing trip in 2009-2011. On the other hand, Yuliana et al. (2016) stated a growing increase in the CPUE of reef fish in the Karimunjawa National Park Conservation Area and is still available monthly and year-round. The size of the fish caught is closely related to the number of trips and the methods used to capture fish by fishermen (Boesono et al., 2011). 
The results study shows that the most important metrics for the domain's sustainability index value are CPUE (3.23) and trends in fish size (3.08) (Figure 4). Trends in CPUE and fish size are heavily affected by non-environmentally friendly fishing practices, such as the use of explosives, resulting in fewer and smaller catches using the hand line by fishermen. Muis et al., $(2019,2020)$ confirmed that some fishermen still use explosives to capture reef fish in the coastal waters of the Spelman Strait. The fishing ground is far from the fish landing site (TPI) because the coral reef environment has been damaged due to destructive fishing that the community has carried out for a long time. All these important qualities need to be strengthened by law implementation and institutional strengthening.

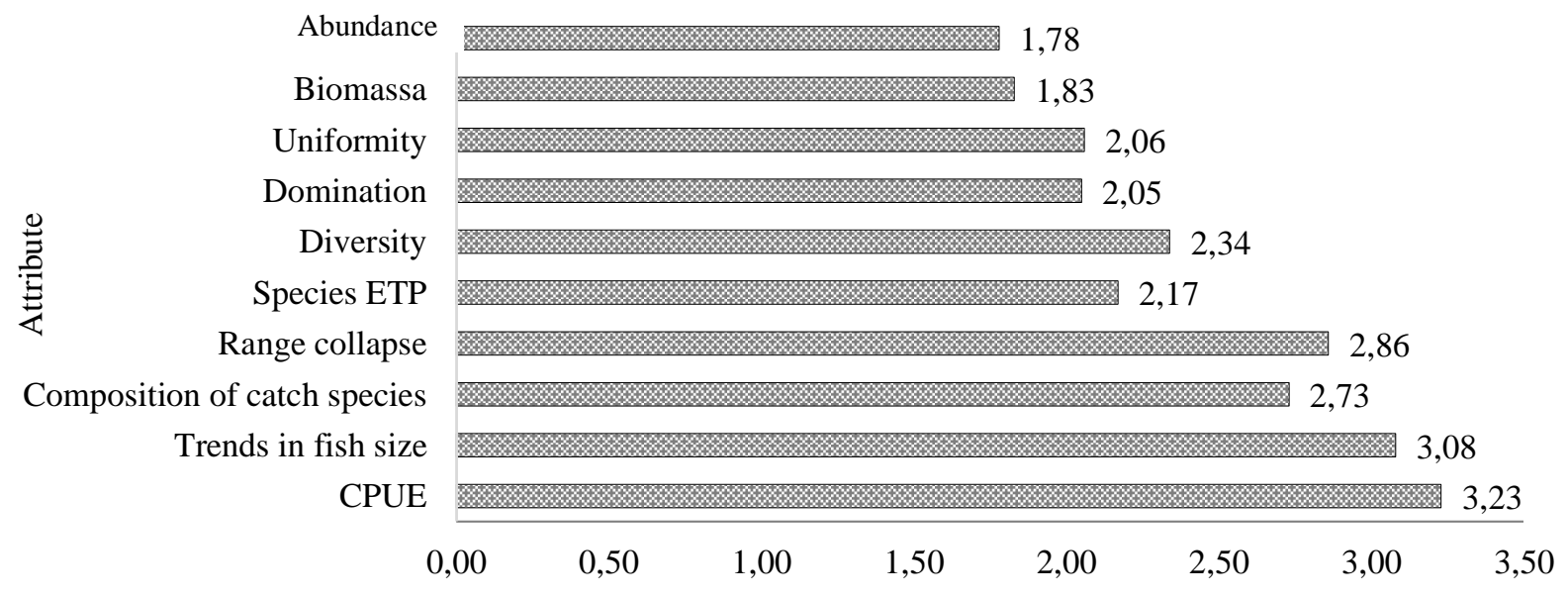

Root Mean Square in Ordination when Selected Attribute (on Sustainability scale 0 to 100)

Figure 4 Factors affecting the fisheries resource domain

\section{Habitat and Ecosystems}

The study of the environment and ecosystem area sustainability status was 88.17 (Figure 2), in sustainable. The high index of sustainability in the area of environment and habitats shows that it still contributes positively to the sustainability of reef fishing and the economy of small-scale fishermen in meeting their needs and improving household welfare. It is important to conserve the coral reef environment and ecosystem through responsible management involving all stakeholders.

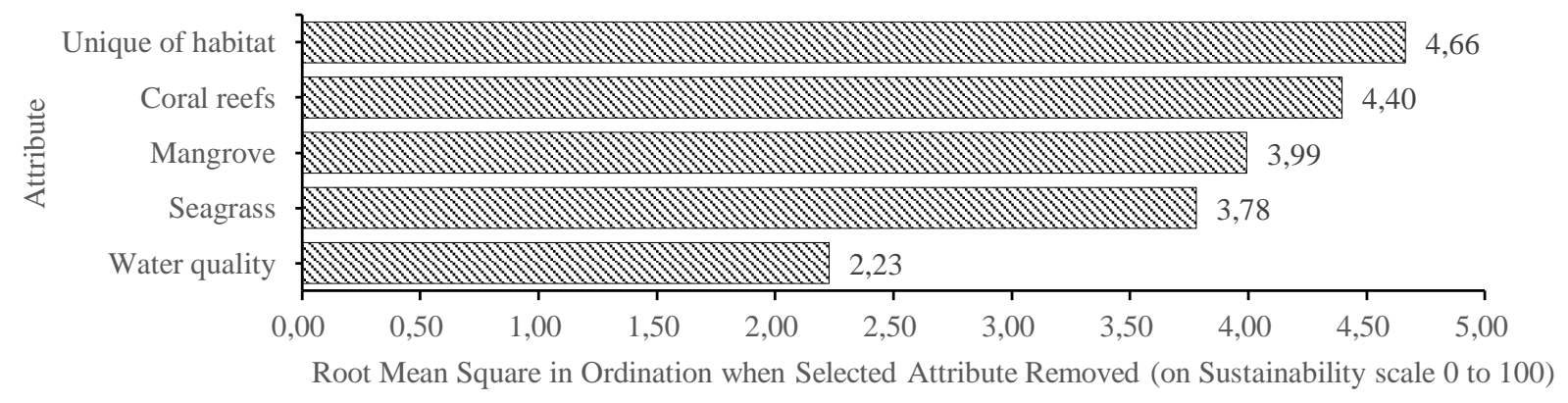

Figure 5 Habitat environment and ecosystem factors

The results of the leverage analysis on the environment and ecosystem domains showed that the metrics most important to the domain of sustainability index rating are unique of habitats and coral reef ecosystems (Figure 5). Muis et al. (2019) reported that the living coral cover in the coastal waters of Spelman Strait were moderate requirements $(37.71 \%)$. The decline in live coral cover has been caused by destructive fishing, as shown during observation by several coral fragments (Muis et al., 2020). Therefore, these two sensitive characteristics need to be managed by carrying out restoration/transplantation of coral reef, especially in the main habitat of fish with high stocks and economic value, such as the Serranidae and Lutjanidae families. 


\section{Domain of Fishing Strategies}

The sustainability status review in the fishery technique domain were 51.22 (Figure 2), which is very sustainable. The fishing gear used until now by fishermen is still conventional (handline). This fishing gear is a known as environmentally friendly since the fish caught is by the fishermen's size of the fishing line. Knowing the fishing pattern is important because it is closely related to the size of the fishing gear used and the type of fish being targeted. Fishermen use various fishing lines, especially in the western season, which is similar to wind and wide waves of water using the fishing line numbered 5-8. Using the hook number 15-18, the eastern season is similar to the relative calm waters. A small proportion of fishermen do use fishing equipment apart from the conventional fishing gear, which threatens to harm the coral reef environment, although this fishing method is prohibited. It's done secretly though, and has been going on for a long time.

The results of the leverage on the fishery resource domain showed that the measures most important to the domain's sustainability index value were destructive selectivity of fishing and fishing gear (Figure 6). Destructive fishing is, according to Campbell et al. (2013), a fishery device that destroys the aquatic environment. As a result, large and small fish are the target of catching (not selective) such that the fishery resources can slowly decrease, and the catch can immediately decrease. It is therefore important to discourage the use of materials that are not environmentally friendly and to implement fair laws and to provide fishermen with knowledge as a means of learning and awareness, in order to enhance the human capital of fishermen.

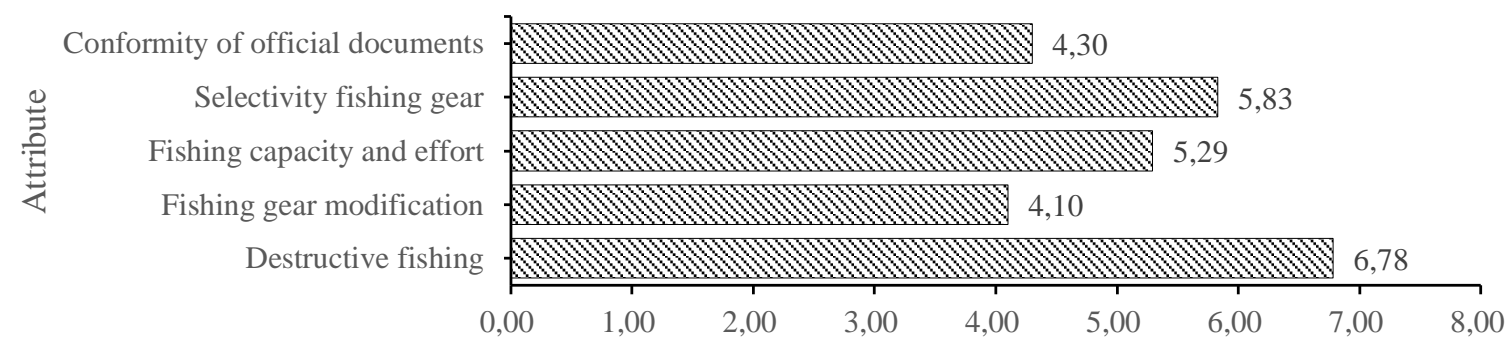

Root Mean Square in Ordination when Selected Attribute Removed (on Sustainability scale 0 to 100$)$

Figure 6 Factors affecting the field of fishery technique

\section{Social Domain}

The findings of the social domain sustainability status review were in the relatively sustainable group at 51.61 (Figure 2). This interest suggests that fishers and society need to become more mindful of the social domain. For fisheries management, knowledge of the community's social structure is very important. Public and fishermen awareness needs to be promoted by stakeholders to keep fisheries management sustainable. Freitag et al. (2019) stated that the sustainable management of resources needs cooperation from all elements of the stakeholders.

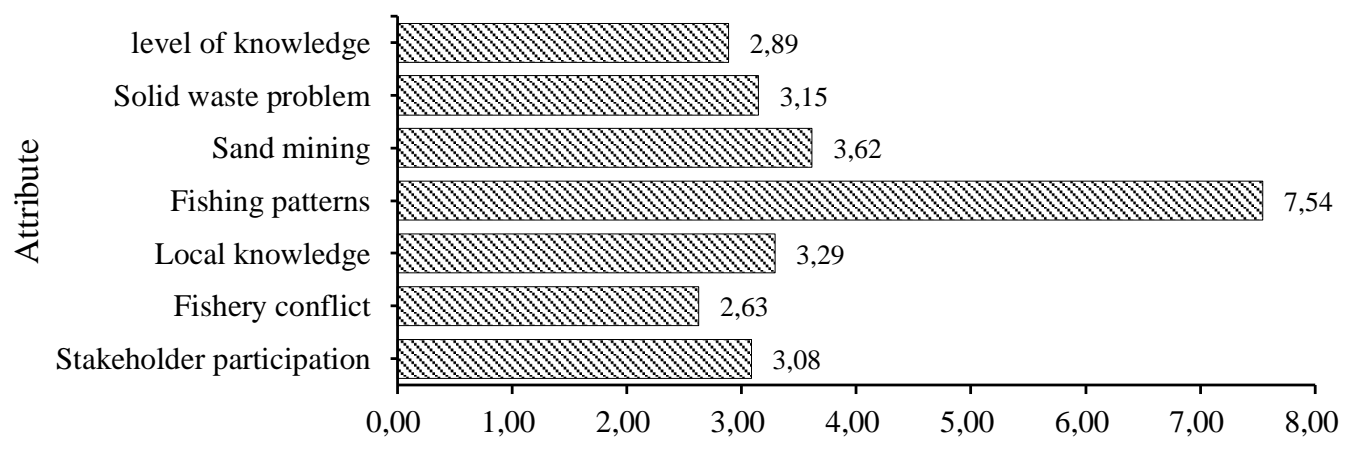

Root Mean Square in Ordination when Selected Attribute Removed (on Sustainability scale 0 to 100)

Figure 7 Factors that influence the social domain 
The results leverage of the social domain showed that the metrics most important to the domain's sustainability index value are fishing patterns and sand mining (Figure 7). Fishing practices that some fishermen already kill in the future cause social tension due to the use of the same resources (Purnama et al., 2015, Lorenzo et al., 2019). As an example, Zulkifli et al. (2019) stated that the degree of fisheries conflict in Kalimantan was triggered by $42 \%$ conflict over resource usage, $38 \%$ conflict over resource use, and $20 \%$ conflict over conflict resource use. Therefore, to improve or preserve the protection of coral reefs management in the social domain of the coastal waters of the Spelman Strait, it is important to ban fishing activities that are not environmentally friendly and to restrict sand mining on the coast with strict regulations to prevent conflicts.

\section{Economic Zone}

The findings of a study of the economic domain sustainability status were 72.67 (Figure 2), in the relatively sustainable range (75-100). This interest suggests that reef fishing contributes significantly to developing the fishing economy.

The results showed that in the economic domain, grab production and employment are the most important measures to the domain's sustainability index value (Figure 8). Fishermen's catch production is decreasing, exacerbated by habitat damage to the coral reef, causing changes. As stated by Rombe et al. (2018), the income of lobster fishermen decreased to Rp 1800 000/month or equivalent to US\$122.26/month due to reduced catch production in Palabuhanratu. The income is below the district minimum wage (UMK) in the Regency of Sukabumi of Rp 3000000 (equivalent to US\$ 203.69). Many of them then exchanged professions as coolies and moved to other regions. Fishers who remain are the Bajo tribe whose whole life depends on the wealth of the fishery. Based on the history of the Bajo tribe, it is a tribe whose lives are dependent on marine resources (sea nomad tribe) and living in coastal areas (Tahara, 2013; Syukur, 2007; Nurhaliza and Suciati, 2019).

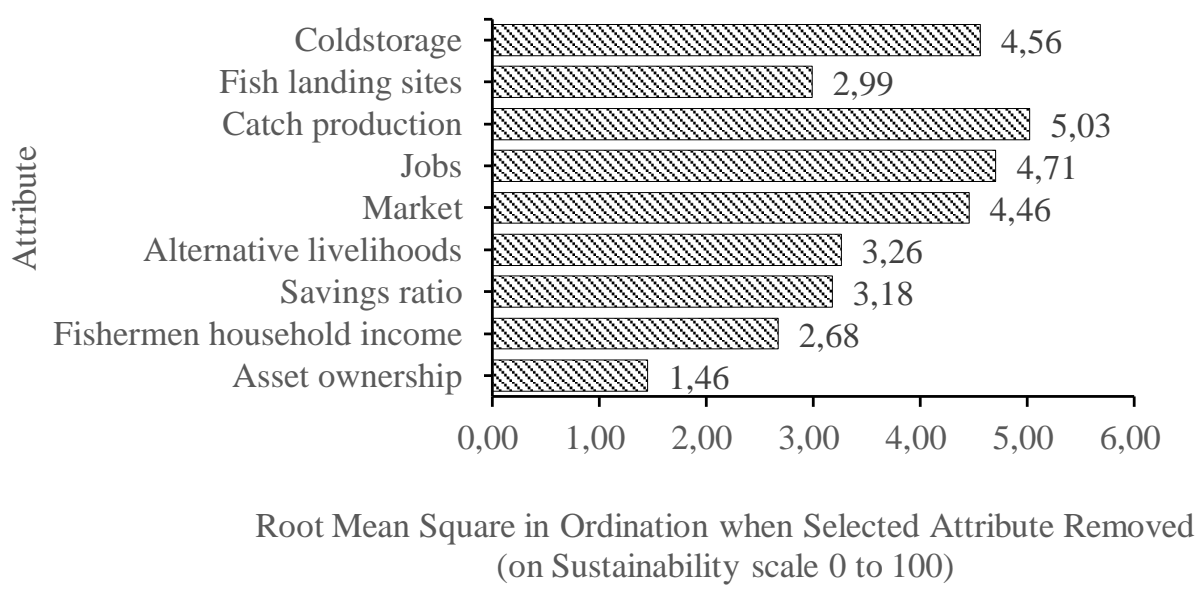

Figure 8 Economic environment factors

\section{Institutional Zone}

The findings of an overview of the institutional domain sustainability status are 42.15 (Figure 2), which was less sustainable. In the institutional domain, the low sustainability index suggests that the poor position of the stakeholders, in this case, local government, is high.

The results study in the institutional domain showed that the metrics most important to the domain's sustainability index importance are the degree of the religious leaders' synergy and participation (Figure 9). Synergy rates amongst local government entities are very low. The identification results indicate that each organization either operates partially or that there is no connection in formulating fisheries management. According to Adrianto (2013), the active involvement of stakeholders in fisheries management is positively associated with the success rate. Beyond that, religious leaders' participation in fisheries management has not yet functioned. Religious figures in Central Buton Regency people's order of life significantly influence group 
conduct patterns. Adrianto et al., (2011) study include religious leaders in managing fishery capital, such as the Kei and Haruku Islands church Sasi and the Ambalau Island Sasi mosque, South Buru Regency. Therefore, it is important to harmonize each institution's programs and include the role of religious leaders in management.

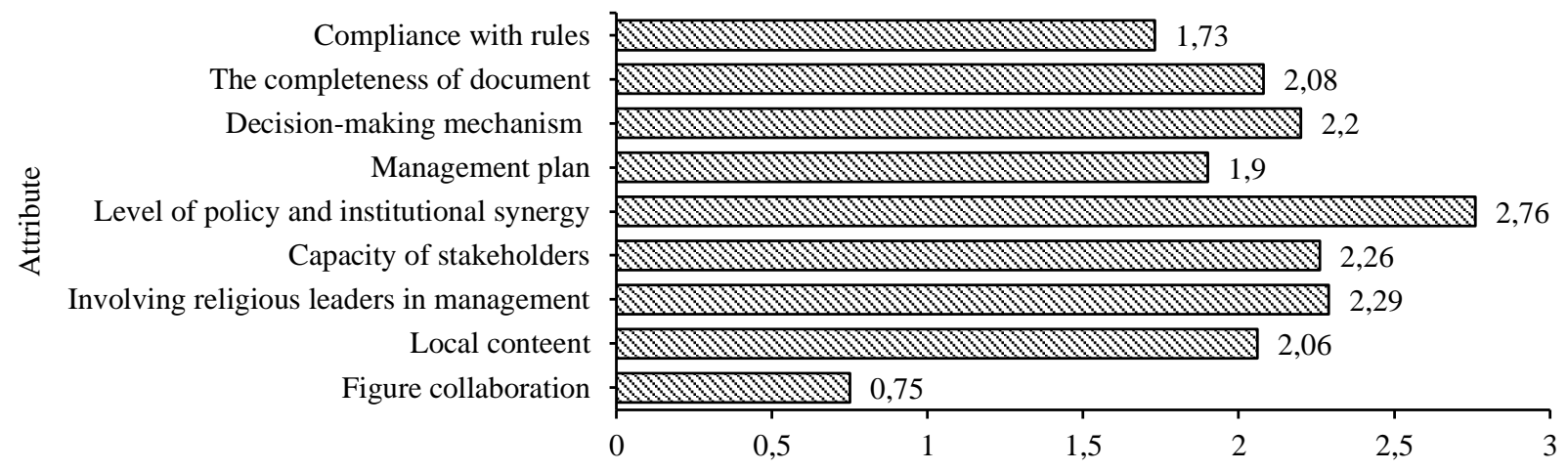

Root Mean Square in Ordination when Selected Attribute Removed (on Sustainability scale 0 to 100)

Figure 9 Factors that influence the institutional domain

Management of the coral fisheries requires a strong commitment from all stakeholder elements. In this situation, the local government serves as a mechanism, through the Central Buton Regency Fisheries and Marine Service, to unite all components with interest in the Spelman Strait. Yuliana et al. (2019) stated that the role of stakeholders in Karimunjawa National Park has a positive effect on the management of the reef fisheries.

The management of coral reefs in the Spelman Strait's coastal waters needs a detailed model to be sustainable. The variables and indicators of the coral fisheries management model developed through MDS acquired many factors that became issues in the sustainability of coral fishing in the Spelman Strait's coastal waters. Such variables, as defined in each domain, require careful handling. According to Ferse et al. (2012), the socio-ecological strategy is very successful in controlling the capital of the coral reef habitats.

\section{CONCLUSION}

Institutions are the primary base for reef fishery protection in the Spelman Strait. Therefore, in the Spelman Strait, the management theory is combined with ecosystem-based management in the form of systemic-based management.

\section{REFERENCES}

[KKP] Kementerian Kelautan dan Perikanan. 2014. Penilaian indikator untuk pengelolaan perikanan dengan pendekatan ekosistem (Ecosystem approach to fisheries management). Jakarta (ID): Direktorat Sumberdaya Ikan, Kementerian Kelautan dan Perikanan.

[KKP] Kementrian Kelautan dan Perikanan, [WWF-Indonesia] World Wide Foundation, [PKSPL-IPB] Pusat Kajian Sumberdaya Laut dan Pesisir, Institut Pertanian Bogor. 2012. Penilaian Indikator Pendekatan Ekosistem Untuk Pengelolaan Perikanan (Ecosystem Approach to Fisheries Management). Training Modul. Jakarta (ID): KKP.

Abidin Z, Primyastanto M. 2017. Sustainability level of management of "Pondok Dadap" fish auction place to support marketing of marine fish in Sendangbiru, East Java. Wacana. 20(4):1-10.

Adrianto L. 2013. Penilaian Indikator Untuk Pengelolaan Perikanan Dengan Pendekatan Ekosistem. Bogor (ID): Pusat Kajian Sumberdaya Pesisir dan Lautan (PKSPL) IPB Kementerian Kelautan dan Perikanan. 
Adrianto L, Amin MAA, Solihin A, Hartoto DI. 2011. Kontruksi lokal pengelolaan sumberdaya perikanan di Indonesia. Bogor (ID): PT. Penerbit IPB Press.

Adrianto L, Ruchimat T, Habibi A. 2016. Building integrated reference indicators and Knowledge Management System for The Implementation of EAFM in Indonesia. Jakarta (ID): National Working Group Ecosystem Approach to Fisheries Management, Ministry of Marine Affairs and Fisheries, Republic of Indonesia.

Allahyari MS. 2010. Social sustainability assessment of fishery cooperatives in Guilan Province, Iran. Journal of Fisheries Aquatic Science. 5(3): 216-222.

Allen G, Adrim M. 2003. Coral reef fishes of Indonesia. Zoological Studies. 42: 1-72.

Baroleh MS, Fahrudin A, Dahuri R, Susilo SB, Monintja D. 2016. Miangas, the outermost small island of Indonesia. International journal of Sciences Basic and Applied Research (IJSBAR). 26(1): 12-25.

Boesono H, Anggoro, Bambang AN. 2011. Laju tangkap dan analisis usaha penangkapan lobster (Panulirus sp.) dengan jaring lobster (Gillnet Monofilament) di Perairan Kabupaten Kebumen. J Saintek Perikanan. 7(1): 77-87.

Campbell SJ, Kartawijaya T, Yulianto I, Prasetia R, Clifton J. 2013. Co-management approaches and incentives improve management effectiveness in the Karimunjawa National Park, Indonesia. Marine Policy. 41: 72-79.

Castello JP, Sunye PS, Haimovici M, Hellebrandt D. 2009. Fisheries in southern Brazil: A comparison of their management and sustainability. J Appl Ichtyol. 25: 287-293.

Cisse AA, Blanchard F, Guyader O. 2014. Sustainability of tropical small-scale fisheries: Integrated assessment in French Guiana. Marine Policy. 44: 397-405.

Erwina Y, Kurnia R, Yonvitner. 2015. Status keberlanjutan sumber daya perikanan di perairan Bengkulu. $J$ Sosek KP. 10(1): 21-34.

Fauzi A, Anna S. 2002. Evaluasi status keberlanjutan pembangunan perikanan: Aplikasi pendekatan rapfish. Jurnal Pesisir dan Lautan. 4(3): 43-55.

Ferse SCA, Glaser M, Neil M, Manez KS. 2012. To cope or to sustain? Eroding longterm sustainability in an Indonesian coral reef fishery. Regional Environmental Change. 14: 2053-2065.

Fitrianti RS, Kamal MM, Kurnia R. 2014. Sustainability analysis of flying fish fisheries in Takalar, South Sulawesi. Depik. 3(2): 118-127.

Freitag A, Vasslides J, Townsend H. 2019. Are you thinking what i'm thinking? A conceptual modeling approach to understand stakeholders'assessments of the fate of Chesapeake oysters. Marine Policy. 99: 99-110.

Hartono TT, Kodiran T, Iqbal MA, Koshendrajana S. 2005. Pengembangan teknik Rapid Appraisal for Fisheries (RAPFISH) untuk penentuan indikator kinerja perikanan tangkap berkelanjutan di Indonesia. Bulletin Ekonomi Perikanan. 6(1): 65-76.

Isaac VJ, Santo RVE, Bentes B, Fredou FL, Mourao KRM, Fredou T. 2009. An interdisciplinary evaluation of fishery production systems off the state of Para in North Brazil. J Appl Ichthyol. 25: 244-255.

Kavanagh P, Pitcher TJ. 2004. Implementing microsoft excel software for rapfish: A technique for the rapid appraisal of fisheries status. Fisheries Centre Research Reports. 12(2).

Kholil, Dewi IJP. 2014. The use of MDS (Multidimensional Scalling) method to analyze the level of sustainability of fisheries resources management in Thousand Islands, Indonesia. International Journal of Marine Science. 4(27): 245-252.

Kuiter RH. 1992. Tropical Reef-Fishes of the Western Pasicific-Indonesia and Adjacent Water. Jakarta (ID): PT. Gramedia Pustaka Utama.

Lessa RP, Monteiro A, Duarte-Neto PJ, Vieira AC. 2009. Multidimensional analysis of fishery production systems in the state of Pernambuco, Brazil. J Appl Ichthyol. 25: 256-268.

Lorenzo IG, Lafuente MMV, Gil MDG. 2019. Adaptive processes in small-scale traditional fisherman's organisations. The case of Cofradias in Galicia (NW Spain). Marine Policy. 99: 382-390. 
Martins AS, dos Santos LB, Pizetta GT, Monjardim C, Doxsey JR. 2009. Interdisciplinary assessment of the status quo of the marine fishery systems in the state of Espirito Santo, Brazil, using Rapfish. J Appl Ichthyol. 25: 269-276.

Muis, Kurnia R, Sulistiono, Taryono. 2019. Coral reefs status and fish species in coastal waters of Spelman Straits, Southeast Sulawesi, Indonesia. AACL Bioflux. 12(5): 2020-2029.

Muis, Kurnia R, Sulistiono, Taryono. 2020. Diversity of coral reef fish in the coastal water of Spelman Straits, Southeast Sulawesi. IOP Conf Series: Earth and Environmental Science. 420: 1-9.

Nababan BO, Sari YD, Hermawan M. 2007. Analisis keberlanjutan perikanan tangkap skala kecil di Kabupaten Tegal Jawa Tengah (teknik pendekatan RAPFISH). J Bijak dan Riset Sosek KP. 2(2): 137158.

Nurhaliza WS, Suciati TN. 2019. Potret social budaya masyarakat Suku Bajo Sampela di Kabupaten Wakatobi. Jurnal Komunikasi Universitas Garut. 5(2): 341-356.

Pitcher TJ. 1999. Rapfish, a rapid appraisal technique for fisheries, and its application to the code of conduct for responsible fisheries. FAO Fisheries Circular No. FIRM/C: No. 947.

Pitcher TJ, Lam M, Ainsworth C, Martindale A, Nakamura K, Perry RI, Ward T. 2013. Improvements to the 'Rapfish' rapid evaluation technique for fisheries: integrating ecological and human dimensions. $J$ Fish Biol. 83: 865-889.

Pitcher TJ, Preikshot DB. 1999. Rapfish: A Rapid Appraisal Technique to Evaluate the Sustainability Status of Fisheries. In: Craig, J. (ed) ICLARM Workshop On Lake Nasser's Fisheries.

Pitcher TJ, Preikshot DB. 2001. Rapfish: A rapid appraisal technique to evaluate the sustainability status of fisheries. Fisheries Research. 49(3): 255-270.

Purnama NR, Simbolon D, Mustaruddin. 2015. Pola pemanfaatan daerah penangkapan ikan untuk mereduksi konflik perikanan tangkap di perairan utara Aceh. Jurnal Teknologi Perikanan dan Kelautan. 6(2): 149158.

Rombe KH, Wardiatno Y, Adrianto L. 2018. Management of lobster fisheries with EAFM approach in Palabuhanratu. Jurnal Ilmu dan Teknologi Kelautan Tropis. 10(1): 231-241.

Supriharyono. 2000. Pelestarian dan Pengelolaan Sumberdaya Alam di Pesisir Tropis. Jakarta (ID): Gramedia.

Syukur M. 2007. Sistem sosial dan kepercayaan Suku Bajo. Attoriolong. 4(1): 86-96.

Tahara T. 2013. Kebangkitan identitas orang Bajo di Kepulauan Wakatobi. Indonesian Journal of Social and Cultural Anthropology. 34(1): 41-55.

Yuliana E, Boer M, Fahrudin A, Kamal MM, Muttaqin E. 2016. Status stok ikan karang target di Kawasan Konservasi Taman Nasional Karimunjawa. Jurnal Penelitian Perikanan Indonesia (JPPI). 22(1): 9-16.

Yuliana E, Boer M, Fahrudin A, Kamal MM, Pardede ST. 2019. Using ecosystem approach indicators for assessing the ecological status of reef fisheries management in a marine protected area. Biodiversitas. 20(7): 1802-1810.

Yulianto I, Hammer C, Wiryawan B, Palm HW. 2016. Fishing-induced groupers stock dynamics in Karimunjawa National Park, Indonesia. Fisheries Science. 81: 417-432.

Zulkifli D, Suyasa IN, Maulita M, Suharti R, Rachmad B, Dewi IJP, Sabariyah N, Mulyono M, Triyono H, Irawan H, Herlambang R. 2019. A conflict analysis of management of fishery resources in Kalimantan, Indonesia. International Journal of Fisheries and Aquatic Study. 7(4): 78-85. 